\title{
Vitamin B12 status among underprivileged preschool children: Experience from two tea estates
}

\author{
*S T Kudagammana ${ }^{1}$, K Mohotti ${ }^{2}$, K Maduwage $^{3}$, S Marasinghe ${ }^{4}$ \\ Sri Lanka Journal of Child Health, 2016; 45(2):111-115
}

\begin{abstract}
Background: Vitamin B12 (B12) is found only in foods of animal origin. The deficiency in children is associated with delay in growth and development, neurological abnormalities and megaloblastic anaemia. There is no prior study done on Sri Lankan children to assess the B12 status.
\end{abstract}

Objective: To find out the serum B12 status in a group of preschool children in the tea estate sector and to assess the risk factors for B12 deficiency

Method: Data was collected from preschool children of St Coombs tea estate, Talawakelle and Idalgashinna Bio tea project, Haldummulla, Haputale. The children were examined by three experienced medical officers for their growth and development and for the presence of other nutritional deficiencies including B12 deficiency. Blood was taken from the children and their mothers for full blood count (FBC) and B12 levels. Blood was analysed for $\mathrm{FBC}$ by an autoanalyser. The blood film was assessed by a Consultant Haematologist for features of B12 deficiency. Serum was separated and stored at $-20^{0} \mathrm{C}$ until the time of analysis. Serum B12 was assessed using an ELISA kit.

Results: There were no children with overt clinical B12 deficiency. The red cell indices and the blood pictures of the children did not reveal haematological features suggestive of B12 deficiency. Due to non-availability of sufficient data on the FBCs of mothers, maternal FBC was not analysed. All the B12 values were above the cut off value of $203 \mathrm{pg} / \mathrm{ml}$. There was no significant difference of B12 values between the Talawakelle and

${ }^{1}$ Senior Lecturer in Paediatrics, Faculty of Medicine, University of Peradeniya, ${ }^{2}$ Research Officer, Tea Research Institute, Talawakelle, ${ }^{3}$ Lecturer in Biochemistry, ${ }^{4}$ Temporary lecturer, Faculty of Medicine, University of Peradeniya

*Correspondence: sanathusara@yahoo.com

(Received on 29 July 2015: Accepted after revision on 29 September 2015)

The authors declare that there are no conflicts of interest

Personal funding was used for this project.

Open Access Article published under the Creative Commons

Attribution CC-BY (CC) the Haputale samples. There was a positive linear relationship between maternal and children's B12 levels in both Haputale and Talawakelle but the associations were not statistically significant

Conclusion: There is no clinical, haematological or biochemical B12 deficiency in the study sample.

(Key words: micronutrient deficiency, vitamin B12 deficiency, malnutrition in Sri Lanka, cobalamin, anaemia in children)

DOI: http://dx.doi.org/10.4038/sljch.v45i2.8118

\section{Introduction}

Total body stores of vitamin B12 (B12) are 2-5 mg, of which half is stored in the liver ${ }^{1}$. The recommended daily intake of B12 is $2 \mu \mathrm{g} /$ day in adults; children require $0.7 \mu \mathrm{g} / \mathrm{day}^{1}$. B12 is found only in foods of animal origin because it is synthesized only by microorganisms. The most common cause for poor B12 status is low dietary intake of the vitamin (i.e. a low intake of foods of animal origin) and malabsorption ${ }^{1}$. The B12 status in Sri Lankan children is hitherto unknown. It can be assumed that B12 deficiency is commoner in underprivileged populations in Sri Lanka because such foods are relatively expensive. Infants are known to develop B12 deficiency when mothers are B12 deficient and the babies are given exclusive breast feeding for longer periods or when fed on diets that are poor in animal foods. The breast-fed infant of a vitamin B12-deficient mother is at risk for B12 deficiency ${ }^{2}$. B12 deficiency is manifested as megaloblastic anaemia and central nervous system (CNS) dysfunction. Severity of megaloblastic anaemia and CNS disease is inversely correlated. Thus markers of megaloblastic anaemia alone are not suitable to diagnose B12 deficiency ${ }^{2}$. Many studies conducted in different parts of the world have shown that B12 deficiency is commoner in the Indian subcontinent, Mexico, Central and South America and selected areas in Africa ${ }^{2}$. A study done on Bhutanese settlers in USA showed a $64 \%$ prevalence of B12 deficiency ${ }^{3}$.

B12 deficiency leads to irritability, abnormal reflexes, feeding difficulties and obtundation leading to coma. If the diagnosis and treatment are delayed it can lead to permanent developmental disabilities because it affects the brain ${ }^{4}$. CNS demyelination may play a role in the pathophysiology of neurological manifestations of B12 deficiency, but how B12 deficiency leads to 
demyelination remains unclear. Studies have shown that reduced S-adenosyl methionine or elevated methylmalonic acid may be involved ${ }^{5}$. Cutaneous manifestations associated with B12 deficiency are skin hyperpigmentation, vitiligo, angular stomatitis and hair changes. Hyperpigmentation of the dorsum of the hands and feet with accentuation over the interphalangeal joints and terminal phalanges along with pigmentation of oral mucosa is characteristic of B12 deficiency ${ }^{6}$.

Tea estate population is considered a socioeconomically deprived group of people in Sri Lanka. Though the average daily income is relatively similar to other comparable Sri Lankan populations, they have many socioeconomic problems in common. Many studies have shown the nutritional status of this population is low compared to the rest of the country ${ }^{7}$. It has been recognized that vegetarianism is a risk factor for the development of B12 deficiency ${ }^{8}$. Because most of the estate community are followers of Hinduism it can be assumed that a significant number of them are vegetarians ${ }^{9}$. Due to these reasons it is likely that vitamin B12 deficiency is common in the estate population. There have been isolated cases of overt vitamin B12 deficiency mainly from estate population. No study in the past has assessed the situation. This is a pilot study to find out the status of B12 deficiency in a group of preschool children in the tea estate sector and to assess the associated risk factors.

\section{Objective}

To find out the serum B12 status in a group of preschool children in the tea estate sector and to assess the risk factors for B12 deficiency

\section{Method}

This was a prospective observational study on clinical, haematological and biochemical assessment of B12 status among pre-school children in 2 tea estates in Sri Lanka. All children between the ages of 1 to 5 years on the day of first interview and whose parents consented to the study were recruited. Children with neurological, gastrointestinal disease and with other organic illnesses which may impair the food intake and the variety were excluded from the study. Data were collected from preschool children of St Coombs tea estate, Talawakelle (Nuwara-Eliya district) and Idalgashinna Bio tea project, Haldummulla, Haputale (Badulla District). A pre-formulated questionnaire was used and data collection was done within a 3 month period from March 2013 to June 2013. The questionnaire was translated into Tamil and validated for the content.

Letters were sent through the superintendents of the two estates to all the parents of children of completed 1 year to completed 5 years. All preschool children whose parents had consented to the study were enrolled. The parents were requested to complete the questionnaire after explaining its contents. Data were collected with regards to their children's birth history, associated medical problems, growth and development and the dietary history with an emphasis on B12 containing foods. Trained people were provided to explain the required fields. They were people who could read and write Tamil which is the commonly spoken language in the estate. They were also workers in the same estate so that the likelihood of getting their help was higher. Parents were provided with respite care to look after irritable babies until they filled the questionnaire. Partially filled questionnaires were encouraged to be completed to minimize incomplete data. Children's growth parameters were measured by a trained laboratory assistant. Children's weights were measured using a calibrated electronic bathroom scale and heights were measured using a stadiometer with standard protocols. They were plotted on the growth chart relevant to age and sex by the research team.

The subjects were examined for clinical features of B12 deficiency. The examining medical officers were given explanations of the clinical features to look for and briefed on the features of B12 deficiency such as pigmentation, tremors, glossitis and easy bruising. Those with probable signs of B12 deficiency were assessed by the chief investigator for verification. Complete neurological examination was performed by the investigators if the history, examination or the cutaneous features were suggestive of B12 deficiency. Blood was drawn by 3 nursing officers experienced in drawing blood from small children after getting informed consent. One sample each was collected for full blood count (FBC) into standard EDTA bottles from the child and the mother. Blood was collected into plain tubes for B12 levels and the serum was separated and frozen at $-20^{\circ} \mathrm{C}$ until the time of analysis.

Blood was analysed for FBC by an autoanalyser. Blood films were prepared from both mothers and children and assessed by a consultant haematologist for features of B12 deficiency. The haematologist was blinded to the clinical details and the B12 levels. B12 concentrations of serum samples were analysed by human B12 ELISA kit (ABO Switzerland, China) according to the manufacturer's guidelines. Purified human B12 antibodies coated microliter plate wells as solid phase antibodies were used. Serum sample of $50 \mu 1$ was added (diluted in five times in assay buffer provide with the kit) to wells and incubated for $30 \mathrm{~min}$ at $37^{\circ} \mathrm{C}$. Then the plate was washed 5 times with wash solution. $50 \mu 1$ of Horse Reddish Peroxidase (HRP) conjugated goat anti-human $\mathrm{B}_{12}$ antibody reagent was added to the wells and incubated for $30 \mathrm{~min}$ at $37^{\circ} \mathrm{C}$. Subsequently the plate was washed 5 times with wash solution and $50 \mu 1$ of tetramethylbenzidine (TMB) substrate solution added and incubated for $30 \mathrm{~min}$ at $37^{\circ} \mathrm{C}$. Finally $50 \mu 1$ of sulphuric acid (stop solution provided with the kit) was added to each well, incubated for 15 minutes at $37^{\circ} \mathrm{C}$ and the absorbance measured at $450 \mathrm{~nm}$. The B12 
concentration was calculated using the standard curve absorbance values obtained with B12 standard solutions provided by the manufacturer. The biochemist was blinded to the clinical details and the FBC / blood picture reports. Data were entered into an Excel worksheet and analysed using SPSS statistical package. Data were analysed to compare the Talawakelle and the Idalgashinna children in relation to growth parameters, B12 features, haematological findings and the B12 levels. Student's t-test was used to compare the 2 sets of B12 levels.

\section{Results}

A total of 83 preschool children in the tea estate, Talawakelle and 113 preschool children in the Idalgashinna Bio tea project, Haldummulla, Haputale participated out of 101 and 120 eligible children respectively. Of the 18 children who did not participate in the study, 17 were non-responders and one was excluded from study because of cerebral palsy. Height and weight analysis in the 2 estates is shown in Table1.

Table 1: Height and Weight analysis

\begin{tabular}{|c|c|c|c|c|}
\hline \multirow[t]{2}{*}{ Centiles } & \multicolumn{2}{|c|}{ Idalgashinna bio tea project $(n=113)$} & \multicolumn{2}{|c|}{ St Coombs estate, Talawakelle $(n=83)$} \\
\hline & $\begin{array}{c}\text { Male }(n=58) \\
\text { No. }(\%)\end{array}$ & $\begin{array}{c}\text { Female }(n=55) \\
\text { No. }(\%)\end{array}$ & $\begin{array}{c}\text { Male }(n=43) \\
\text { No. }(\%)\end{array}$ & $\begin{array}{c}\text { Female }(n=40) \\
\text { No. }(\%)\end{array}$ \\
\hline $\begin{array}{l}\text { Heights } \\
\text { below } 3^{\text {rd }} \text { centile } \\
\text { between } 3^{\text {rd }} \text { and } 10^{\text {th }} \text { centile } \\
\text { above } 10^{\text {th }} \text { centile }\end{array}$ & $\begin{array}{l}11(19.0) \\
07(12.0) \\
40(69.0)\end{array}$ & $\begin{array}{l}16(29.1) \\
12(21.8) \\
27(49.1) \\
\end{array}$ & $\begin{array}{l}10(23.2) \\
06(14.0) \\
27(62.8) \\
\end{array}$ & $\begin{array}{l}10(25.0) \\
09(22.5) \\
21(52.5)\end{array}$ \\
\hline $\begin{array}{l}\text { Weights } \\
\text { below } 3^{\text {rd }} \text { centile } \\
\text { between } 3^{\text {rd }} \text { and } 10^{\text {th }} \text { centile } \\
\text { above } 10^{\text {th }} \text { centile }\end{array}$ & $\begin{array}{l}08(13.8) \\
08(13.8) \\
42(72.4)\end{array}$ & $\begin{array}{l}12(21.8) \\
04(07.3) \\
39(70.9)\end{array}$ & $\begin{array}{l}16(37.2) \\
05(11.6) \\
22(51.2)\end{array}$ & $\begin{array}{l}25(62.5) \\
12(30.0) \\
03(07.5)\end{array}$ \\
\hline
\end{tabular}

Meat and fish consumption is shown in Table 2 and consumption of foods of high vitamin $\mathrm{B}$ content other than meat or fish in Table 3 . There were $23(20.4 \%)$ children from the Idalgashinna Bio tea project and 08 $(9.6 \%)$ from the Talawakelle tea estate who did not consume meat or fish at all.

Table 2: Meat and fish consumption

\begin{tabular}{|l|c|c|}
\hline \multicolumn{1}{|c|}{ Food consumed } & $\begin{array}{c}\text { Idalgashinna bio } \\
\text { tea project, } \\
\text { Haputale }(\boldsymbol{n = 1 1 3 )} \\
\text { No. (\%) }\end{array}$ & $\begin{array}{c}\text { St Coombs Estate } \\
\text { Talawakelle } \\
(\boldsymbol{n = 8 3 )} \\
\text { No. (\%) }\end{array}$ \\
\hline Meat Consumption & $42(37.2)$ & $13(15.7)$ \\
Number of subjects who have never/rarely consumed meat & $34(30.1)$ & $37(44.6)$ \\
Number of subjects who have consumed once or twice a week & $10(08.8)$ & $22(26.5)$ \\
Number of subjects who have consumed more than twice a week & $27(23.9)$ & $11(13.2)$ \\
Incomplete information & $26(23.0)$ & $10(12.0)$ \\
\hline Fish Consumption & $45(39.8)$ & $32(38.6)$ \\
Number of subjects who have never/rarely consumed fish & $14(12.4)$ & $26(31.3)$ \\
Number of subjects who have consumed once or twice a week & $28(24.8)$ & $15(18.1)$ \\
Number of subjects who have consumed more than twice a week & & \\
Incomplete information & & \\
\hline
\end{tabular}

Table 3: Consumption of foods of high vitamin B12 content other than meat or fish

\begin{tabular}{|l|c|c|c|c|}
\hline \multicolumn{1}{|c|}{ Location } & \multicolumn{4}{c|}{ Food item No. (\%) } \\
\hline St Coombs estate, Talawakelle & Butter & Margarine & Milk & Eggs \\
\cline { 2 - 5 } Never or rarely & $29(34.6)$ & $29(34.6)$ & $08(09.9)$ & $07(08.7)$ \\
Once or twice weekly & $16(19.8)$ & $17(21.0)$ & $01(01.2)$ & $41(49.4)$ \\
3 or more per week & $14(17.3)$ & $11(13.6)$ & $57(69.1)$ & $21(24.7)$ \\
Incomplete information & $24(28.3)$ & $26(31.8)$ & $17(19.8)$ & $14(17.2)$ \\
\hline Idalgashinna bio tea project, Haputale & & & & \\
Never or rarely & $32(28.0)$ & $37(33.1)$ & $25(22.0)$ & $39(34.7)$ \\
Once or twice weekly & $27(23.7)$ & $24(21.2)$ & $22(19.5)$ & $30(26.3)$ \\
3 or more per week & $12(11.0)$ & $14(11.9)$ & $47(41.5)$ & $23(20.3\}$ \\
Incomplete information & $42(37.3)$ & $38(33.8)$ & $19(17.0)$ & $21(18.7)$ \\
\hline
\end{tabular}


Clinical features of vitamin B12 deficiency

There were no children with typical hyperpigmentation over the dorsum of the hands and the feet associated with B12 deficiency. This may be easily overlooked in the dark skinned population. There were 2 patients with angular stomatitis without glossitis.

Haematological indices and blood picture

Among the 28 children from 1 year to 2 years there were 12 having low haemoglobin for the age $(<11 \mathrm{~g} / \mathrm{dl})$. Thirty one out of 61 children in the 2-6 year category were anaemic $(-2 \mathrm{SD}: 11.5 \mathrm{~g} / \mathrm{dl})^{10}$. All the anaemic children had microcytic hypochromic red cells suggestive of iron deficiency. There was no child with macrocytic anaemia in the assessment of the blood pictures. Due to non-availability of sufficient data on the FBCs of mothers, maternal FBC was not analysed.

All the B12 values were above the cut off value of $203 \mathrm{pg} / \mathrm{ml}$. The cut off value was taken from Conclusions of a WHO technical consultation on folate and $\mathrm{B} 12$ deficiencies ${ }^{11}$. There was no significant difference of B12 values between the Talawakelle and the Haputale samples. There was a positive linear relationship between maternal and children's B12 levels in both Haputale and Talawakelle but the associations were not statistically significant (Figure 1).

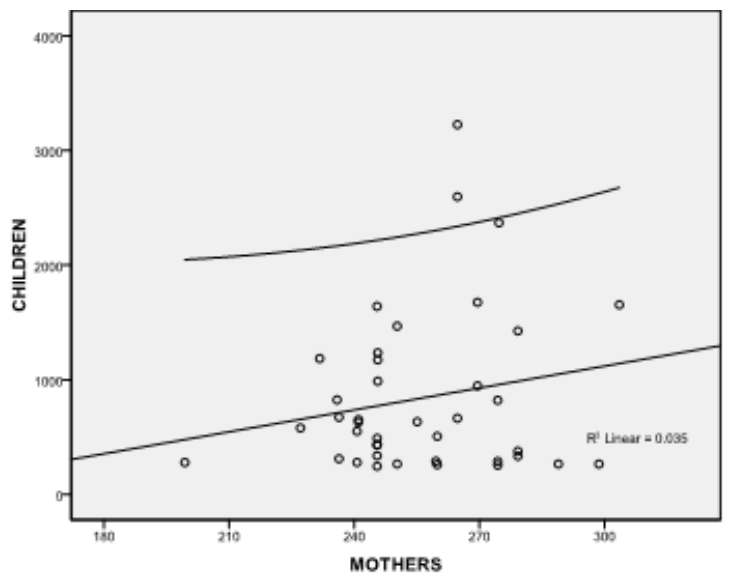

Figure 1: Vitamin B12 levels of mothers and children

\section{Discussion}

The study was done on a socioeconomically deprived population in Sri Lanka. The estate population which descends from South India has an identity of their own. The food preferences are different to the rest of the population. The dietary history was taken after a selfcompleted questionnaire. It has its own deficiencies such as the impact of literacy. Measures were taken to minimize the errors. We used period recall to assess their intake of foods that contain higher level of B12. We did not assess the quantity of each. It has been shown that 24 hour recall supplemented by additional 3 interviews over a period of 1 year is the easiest and most cost effective method to evaluate food intake ${ }^{10}$. Though the estate population is considered an underprivileged group, their milk and egg consumption is relatively high as shown in Table 3 . Both these items are relatively easily available through domestic production. This may be the reason for the absence of B12 deficiency in spite of low intake of meat/fish products.

\section{Conclusions}

There is no clinical, haematological or biochemical evidence of vitamin B12 deficiency in the study sample.

\section{References}

1. Allen LH. Causes of vitamin B12 and folate deficiency. Food and Nutrition Bulletin 2008; 29(2 Suppl.): S20-34. http://dx.doi.org/10.1177/15648265080292S10 5

PMid: 18709879

2. Stabler SP, Allen RH. Vitamin B12 deficiency as a worldwide problem. Annual Review of Nutrition 2004; 24: 299-326.

http://dx.doi.org/10.1146/annurev.nutr.24.0120 03.132440

PMid: 15189123

3. Vitamin B12 deficiency in resettled Bhutanese refugees- United States 2008- 2011. Morbidity Mortality Weekly Reports 2011; 60: 343-6.

4. Graham SM, Arvela OM, Wise GA. Long term neurological consequences of nutritional vitamin B12 deficiency in infants. Journal of Pediatrics 1992; 121; 710-4. http://dx.doi.org/10.1016/S00223476(05)8189 7-9

5. Singh NN. Vitamin B-12 Associated Neurological Diseases. Available from: http://emedicine.medscape.com/article/115267 0-overview

6. Kannan R, Ming Ng MJ. Cutaneous lesions and vitamin B12 deficiency: An oftenforgotten link. Canadian Family Physician 2008; 54(4); 529-32.

PMid: 18413300 PMCid: PMC2294086

7. Malnutrition in Sri Lanka: Scale, scope, causes and potential response. World Bank Report no. 40906. Sep 2007: 1-6. Available from: http://documents.worldbank.org/curated/en/20 07/09/8996660/ 
8. Heemann W, Schorr H, Obeid R, Geisel J. Vitamin B12 status, particularly holotranscobalamin 11 and methylmalonic acid concentrations and hyperhomocysteinaemia in vegetarians. American Journal of Clinical Nutrition 2003; 78: 1131-6.

9. Chanarin I, O'hea A, Malkowska V, Rinsler MG, Price AB. Megaloblastic anaemia in a vegetarian Hindu community. The Lancet 1985; 326(8465): 1168-72.

http://dx.doi.org/10.1016/S01406736(85)9269

$0-\mathrm{X}$
10. Morgan KJ, Johnson SR, Rizek RL, Reese $\mathrm{R}$, Stampley GL. Collection of food intake data: an evaluation of methods. Journal of the American Dietetic Association 1987; 87(7): 888-96.

PMid: 3598037

11. De Benoist B. Conclusions of a WHO technical consultation on folate and vitamin B12 deficiencies. Food and Nutrition Bulletin 2008; 29:S238-44.

http://dx.doi.org/10.1177/15648265080292S12 9

PMid: 18709899 